\title{
ПОКАЗНИКИ ОБМІНУ ЗАЛІЗА ЗАЛЕЖНО ВІД ФУНКЦІОНАЛЬНОГО КЛАСУ ХРОНІЧНОЇ СЕРЦЕВОЇ НЕДОСТАТНОСТІ У ПАЦІЄНТІВ ІЗ СУПУТНІМ ЗАЛІЗОДЕФІЦИТОМ
}

\author{
Вінницький національний медичний університет імені М. І. Пирогова, м. Вінниця, Україна
}

Мета: проаналізувати значення показників червоної крові та ферокінетики залежно від фрункціонального класу (ФК) ХCH зі зниженою фрракцією викиду (зниж ФВ) лівого шлуночка (ЛШ) у пацієнтів із супутнім залізодесріцитом.

Матеріали і методи. У дослідженні проведено аналіз гематологічних показників та показників ферокінетики 122 хворих на хронічну серцеву недостатність гіпертензивної в поєднанні з ішемічною етіологією зі зниженою фрракцією викиду лівого шлуночка та супутнім залізодесріцитом залежно від величини фрункціонального класу хронічної серцевої недостатності.

Результати. Виявлено, що у пацієнтів із супутнім латентним ЗД та залізодефріцитною анемією (ЗДА) зі збільшенням ФК ХСН зменшуються показники ферокінетики. У групі хворих на ХСН зі знижФВ із супутньою ЗДА серед пацієнтів III ФК були достовірно нижчі середні значення Hb, Hct, та кількості Rbc порівняно $з$ середніми значеннями даних показників пацієнтів II ФК цієї ж групи. Серед показників фрерокінетики були достовірно нижчі середні рівні фреритину, насичення трансфрерину залізом та достовірно вищий рівень залізозв'язувальної здатності сироватки крові. У групі хворих на ХСН зі знижФВ із латентним ЗД III ФК достовірна відмінність була виявлена лише за значенням НТ3.

Висновки. Найпоказовішими серед гематологічних показників та показників ферокінетики щодо фрізичної активності хворих на ХCH при ЗДА є Hb, Hct, Rbc, фреритин та HT3, низькі значення яких асоціюються 3 вищим ФК.

Зниження НТЗ свідчить про погіршення фрункціонального стану хворих на ХCH зі знижФВ із супутнім ЗД як 3 анемією, так і без.

КЛЮчОВІ СЛОВА: хронічна серцева недостатність; латентний залізодефіцит; залізодефріцитна анемія; показники ферокінетики.

Хронічна серцева недостатність є наслідком прогресування багатьох серцево-судинних захворювань, особливо таких, як ішемічна хвороба серця (IXC), гіпертонічна хвороба (ГX) та їхнє поєднання [2, 4]. Поширеність залежить від застосовуваних критеріїв для визначення СН. У розвинених країнах її поширеність становить 1,5-5 \% від дорослої популяції, а в осіб віком $>70$ років вона зростає до $\geq 10 \%$ [2]. У результаті удосконалення терапії та її впровадження у клінічну практику поліпшилась виживаність і зменшилась частота госпіталізацій хворих із СН зі зниженою фрракцією викиду лівого шлуночка, хоча її прогноз часто залишається незадовільним. Частота летальних випадків від усіх причин протягом року в госпіталізованих і стабільних амбулаторних хворих на ХCH становить 17 і 7 \% відповідно, а частота госпіталізацій - 44 і 32 \% відповідно [7].

Дослідження останніх років зосереджені на поєднанні ХCH із різними коморбідними станами, які значно ускладнюють її перебіг, впливають на прогноз та якість життя (ЯЖ) пацієнтів [6]. Так з практичної точки зору, є досить актуальною проблема поєднання ХCH із залізодефіцитом. Оскільки ЗД

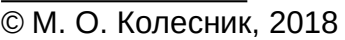

при СН, як і при інших хронічних захворюваннях, спостерігають часто і може спричинити розвиток анемії і/або дисорункції скелетних м'язів навіть у пацієнтів без анемії [14].

Поглиблене вивчення поєднання ЗД із ХCH зумовлено погіршенням прогнозу $[15,16]$ та фрункціонального стану таких хворих. Позитивні результати декількох плацебо-контрольованих досліджень із застосуванням сахарози і мальтози заліза щодо істотного поліпшення фрункціонального і клінічного статусу та ЯЖ пацієнтів із $\mathrm{CH}$ зі знижФВ ЛШ, а також зменшення ризику їх госпіталізації $[9,12,17]$ дозволили припустити, що саме ЗД є предиктором несприятливого прогнозу і незалежною від анемії новою терапевтичною мішенню та потребує подальшого детального вивчення.

Мета дослідження: проаналізувати значення показників червоної крові та фрерокінетики залежно від функціонального класу $\mathrm{XCH}$ зі зниженою фракцією викиду лівого шлуночка у пацієнтів із супутнім ЗД.

Матеріали і методи. У проведене дослідження включено 152 пацієнта із $\mathrm{XCH}$ зі знижФВ лш II-III ФК за NYHA гіпертензивної в поєднанні 3 ішемічною етіологією з/та без супутнього ЗД. 
Вік хворих коливався 48-79 років, у середньому - $(69,4 \pm 0,63)$ року. Усі хворі перебували на стаціонарному лікуванні у терапевтичних відділеннях Вінницького обласного клінічного госпіталю

ветеранів війни у період з 2013 до 2017 рр. Серед включених пацієнтів 72,4 \% (110 із 152) чоловіки і 27,6 \% (42 із 152) - жінки (табл. 1).

Таблиця 1. Клінічна характеристика хворих, включених у дослідження

\begin{tabular}{|l|c|}
\hline \multicolumn{1}{|c|}{ Показники } & Кількість хворих (n=152) \\
\hline Середній вік (роки) & $69,4 \pm 0,63$ \\
& $70,5(48-79)$ \\
\hline Зрілий вік (45-59 років) & $19(12,5 \%)$ \\
Похилий вік (60-75 років) & $93(61,2 \%)$ \\
Старечий вік (>75 років) & $40(26,3 \%)$ \\
\hline Чоловіки & $110(72,4 \%)$ \\
\hline Жінки & $42(29,6 \%)$ \\
\hline ХСН II ФК за NYНА & $45(29,6 \%)$ \\
ХСН III ФК за NYНА & $107(70,4 \%)$ \\
\hline Тривалість ГХ (роки) & $18,1 \pm 0,5$ \\
\hline Стабільна стенокардія напруження, зокрема: & $59(38,8 \%)$ \\
II ФК & $17(28,8 \%)$ \\
III ФК & $42(71,2 \%)$ \\
\hline Інфраркт міокарда в анамнезі, & $49(32,2 \%)$ \\
3 них повторні: & $15(30,6 \%)$ \\
\hline ФП постійна фрорма & $40(26,3 \%)$ \\
\hline Блокади ніжок пучка Гіса & $105(69,0 \%)$ \\
\hline
\end{tabular}

Діагноз ХСН встановлювали відповідно до діючих рекомендацій Асоціації кардіологів України 3 діагностики та лікування хронічної серцевої недостатності, 2017; ESC guidelines for the diagnosis and treatment of acute and chronic heart failure, 2016.

Для діагностики та верифрікації ЗД використовували критерії, які адаптовані для пацієнтів із XCH (J. N. Nanas, C. Matsouka, D. Karageorgopoulos [et al.], 2006; D. O. Okonko, A. Grzeslo, T. I. Witkowsk, A. K. Mandal, 2008; S. D. Anker, J. C. Colet, G. Filippatos [et al.], 2009; P. Ponikowski, 2015): істинний ЗД - при зниженні заліза сироватки (3С) і рівні фреритину <100 нг/мл; фрункціональний ЗД при зниженні 3С, рівні фееритину 100-300 нг/мл і насиченні транссрерину залізом <20 \%. При відсутності ознак анемії ЗД розглядали як латентний. Залізодефріцитну анемію (ЗДА) діагностували при наявності ознак істинного ЗД і зниженні рівня гемоглобіну $(\mathrm{Hb})$ у венозній крові <130 г/л у чоловіків і $<120$ г/л у жінок. Анемію легкого ступеня визначали у разі значень $\mathrm{Hb}-110-119$ г/л для жінок та 110-129 г/л для чоловіків, помірного в межах 109-80 г/л і тяжкого <80 г/л як для жінок, так і для чоловіків згідно з чинними рекомендаціями (ВОО3, 2011).

Усім пацієнтам проводили загальноклінічне обстеження: оцінку скарг, анамнезу, фрізикальне обстеження. Лабораторні методи включали загальний аналіз крові (показники $\mathrm{Hb}$, еритроцитів (Rbc), кольоровий показник (КП), лейкоцитів, лейкограма, ШОЕ, гематокрит (Hct) та розрахункові еритроцитарні індекси - середній об'єм еритроцитів (MCV), середній вміст Нb в еритроцитах (MCH), середню концентрацію Нb в еритроциті (МСНC). Основні біохімічні показники, за якими оцінювали стан обміну заліза в організмі: рівень 3С (негемоглобінового) крові, рівень феритину, залізозв'язувальної здатності сироватки (333С) крові та розрахунковий показник насичення трансфрерину залізом.

Статистичну обробку отриманих результатів проводили за допомогою програмного пакета Microsoft Office Excel. Статистичну значущість отриманих вимірювань при порівнянні середніх величин визначали за критерієм Стьюдента та U-критерієм Манна-Уїтні при малій вибірці 3 обчисленням ймовірності помилки (р). Достовірність різниці частоти реєстрації різних ознак у групах визначали за критерієм Стьюдента для порівняння відносних величин.

Усі пацієнти залежно від показників обміну заліза та гемограми були поділені на три клінічні групи: першу (представлена як група порівняння) склали 30 (19,7 \%) пацієнтів із ХСН зі знижФВ без ЗД, другу - 60 (39,5 \%) пацієнтів із ХСН зі знижФВ і латентним ЗД та третю - 62 (40,79 \%) хворих на $\mathrm{XCH}$ із знижФВ та ЗДА легкого та середнього ступенів тяжкості (пацієнти 3 тяжкою анемією не були включені у дослідження). Основний клінічний масив склали саме 122 пацієнта 3 XCH зі знижФВ і супутнім ЗД. Групи хворих були зіставлені за статтю, віком, клінічними характеристиками як, IM у анамнезі, стадії XCH та постійною формою фрібриляції передсердь (ФП). 
Результати дослідження та їх обговорення. Результати лабораторного дослідження свідчили, що між групою порівняння і пацієнтами із супутньою ЗДА достовірні відмінності були виявлені за величиною усіх гематологічних та розрахункових параметрів загального аналізу крові (табл. 2). У пацієнтів із латентним ЗД виявлені достовірні відмінності лише за величиною КП. Відмінностей щодо концентрації $\mathrm{Hb}$, кількості Rbc, величини Hct не було виявлено, що відповідає критеріям латентного ЗД, який характеризується зниженням вмісту депонованого, транспортного заліза і залізовмісних ферментів та нормальними показниками еритробластного відростка червоного кісткового мозку. Також не було виявлено значущої різниці між групою порівняння і пацієнтами із ХCH зі знижФВ і супутнім латентним ЗД за розрахунковими еритроцитарними індексами $\mathrm{MCV}, \mathrm{MCH}, \mathrm{MCHC}$, що узгоджується з попередньо проведеними дослідженнями (М. Н. Зенина, 2013; І. І. Зелена, 2006), в яких не було виявлено статистично підтвердженої різниці значень еритроцитарних параметрів від груп порівняння.

Оцінюючи показники ферокінетики, середня концентрація 3С сироватки крові у групі хворих на XCH зі знижФВ із супутнім ЗДА була нижчою на 53,6 \% та у групі із супутнім латентним ЗД на $52,5 \%$, ніж у хворих групи порівняння без ЗД $((8,4 \pm 0,3)$ та $(8,6 \pm 0,2)$ проти $(18,1 \pm 0,6)$ мкмоль/л відповідно). Також в обох групах були достовірно вищими середні величини 333С та достовірно нижчими середні рівні феритину. Рівні НТЗ як ключового показника зниження ЗС крові у групі хворих на ХСH зі знижФВ із супутньою ЗДА на $62,1 \%$ та у групі із супутнім латентним ЗД на 55,2 \% були нижчими, ніж у хворих групи порівняння $((13,6 \pm 0,5)$ та $(11,3 \pm 0,5)$ проти $(30,6 \pm 1,1) \%$ відповідно).

Таблиця 2. Морфофункціональна характеристика еритроцитів і показники обміну заліза у хворих на хронічну серцеву недостатність зі зниженою фракцією викиду лівого шлуночка

\begin{tabular}{|c|c|c|c|c|c|}
\hline \multirow[b]{2}{*}{ Показники } & \multirow{2}{*}{$\begin{array}{c}\text { І група } \\
\text { ХСН зі знижФВ без } \\
\text { ЗД (порівняння) } \\
(n=30)\end{array}$} & \multicolumn{4}{|c|}{ ХСН зі знижФВ із супутнім ЗД (n=122) } \\
\hline & & $\begin{array}{c}\text { II група } \\
\text { латентний 3Д } \\
(n=60)\end{array}$ & $\mathrm{p}_{1}$ & $\begin{array}{c}\text { III група ЗДА } \\
(n=62)\end{array}$ & $\mathrm{p}_{2}$ \\
\hline $\mathrm{Hb}$ (г/л) & $138,8 \pm 2,0$ & $135,8 \pm 1,1$ & $>0,05$ & $106,0 \pm 2,2$ & $<0,001$ \\
\hline $\mathrm{Rbc}\left(\times 10^{12} / л\right)$ & $4,7 \pm 0,09$ & $4,7 \pm 0,05$ & $>0,05$ & $4,1 \pm 0,09$ & $<0,001$ \\
\hline КП & $0,90 \pm 0,007$ & $0,86 \pm 0,006$ & $<0,001$ & $0,77 \pm 0,015$ & $<0,001$ \\
\hline Hct (л/л) & $0,41 \pm 0,01$ & $0,40 \pm 0,003$ & $>0,05$ & $0,33 \pm 0,006$ & $<0,001$ \\
\hline MCV (фрл) & $87,5 \pm 1,1$ & $85,3 \pm 0,8$ & $>0,05$ & $79,5 \pm 1,4$ & $<0,001$ \\
\hline $\mathrm{MCH}(п г)$ & $29,5 \pm 0,4$ & $28,8 \pm 0,2$ & $>0,05$ & $25,5 \pm 0,5$ & $<0,001$ \\
\hline $\mathrm{MCHC} \mathrm{(г/л)}$ & $338,0 \pm 3,4$ & $338,4 \pm 2,4$ & $>0,05$ & $321,2 \pm 5,8$ & $<0,01$ \\
\hline 3С (мкмоль/л) & $18,1 \pm 0,6$ & $8,6 \pm 0,2$ & $<0,001$ & $8,4 \pm 0,3$ & $<0,001$ \\
\hline Феритин (мкг/л) & $183,1 \pm 21,4$ & $95,7 \pm 7,4$ & $<0,001$ & $55,6 \pm 3,2$ & $<0,001$ \\
\hline HT3 (\%) & $30,6 \pm 1,1$ & $13,6 \pm 0,5$ & $<0,001$ & $11,3 \pm 0,5$ & $<0,001$ \\
\hline 33ЗС (мкмоль/л) & $59,8 \pm 1,3$ & $64,7 \pm 1,2$ & $<0,01$ & $76,5 \pm 1,3$ & $<0,001$ \\
\hline
\end{tabular}

Примітки: $\mathrm{p}_{1,2}$ - достовірність відмінностей показників порівняно із групою хворих на ХСН без ЗД.

Згідно з рекомендаціями Асоціації кардіологів України з діагностики та лікування ХСН (2017) спостерігали, що в проведене дослідження увійшли лише пацієнти із ХCH зі знижФВ, II-А стадією за Стражеско-Василенко і II-III ФК за NYHA. В обох клінічних групах із супутнім порушенням обміну заліза спостерігали перевагу за частотою реєстрації випадків XСН III ФК (рис. 1), що узгоджується $з$ даними літератури $[1,8]$.

Основну роль у погіршенні переносимості фрізичного навантаження за умов ЗД, ймовірно, відіграють порушення функції скелетних м'язів і «негемодинамічні» наслідки посилення нейрогуморальної активації, пов'язаної з потребою у збільшенні транспортування кисню до тканин [6]. Оскільки відомо, що ЗД впливає на функціональну здатність пацієнтів із $\mathrm{XCH}$, був проведений аналіз показників червоної крові та фрерокінетики у хворих на ХCH зі знижФВ та супутнім порушенням обміну заліза залежно від ФК (табл. 3).

У групі хворих на ХCH зі знижФВ із супутньою ЗДА серед пацієнтів III ФК були достовірно нижчі середні значення $\mathrm{Hb}-(103,3 \pm 1,5)$ г/л $(p<0,001)$, Hct - $(0,32 \pm 0,004)$ л/л $(p<0,01)$ та кількості Rbc $(4,0 \pm 0,06) \times 10^{12} / л \quad(p<0,01)$ порівняно 3 середніми значеннями даних показників пацієнтів ІІ ФК цієї ж групи - $(115,4 \pm 6,9)$ г/л, $(0,35 \pm 0,02)$ л/л та $(4,4 \pm 0,27) \times 10^{12} / л$ відповідно. Середні значення КП та еритроцитарних параметрів також були нижчими, але недостовірно ( $p>0,05)$.

Аналізуючи значення показників фрерокінетики у хворих на ХCH із супутньою ЗДА серед пацієнтів III ФК були достовірно нижчі середні рівні фреритину $(52,5 \pm 3,7)$ мкг/л $(p<0,05)$, НТ3 - $(10,7 \pm 0,6) \%$ 


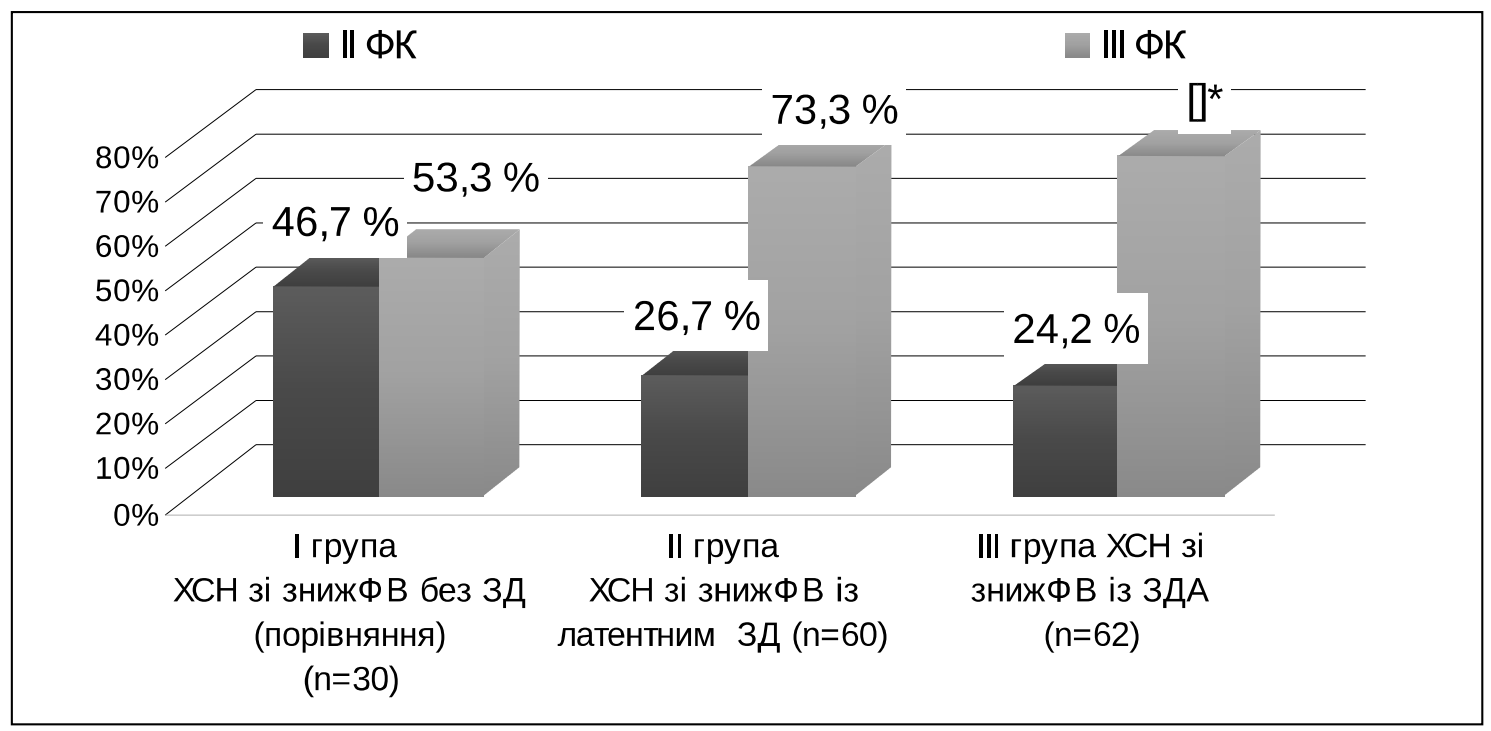

Рис. 1. Розподіл хворих із II та III ФК ХСН серед клінічних груп.

Примітки: Достовірність різниці частоти реєстрації різних ФК у кожній групі та між групами розрахована за t-критерієм Стьюдента для порівняння відносних величин; «»-достовірність різниці із першою групою $($ р<0,05).

Таблиця 3. Гематологічні показники та показники обміну заліза у хворих на хронічну серцеву недостатність зі зниженою фракцією лівого шлуночка різних функціональних класів

\begin{tabular}{|c|c|c|c|c|c|c|}
\hline \multirow[t]{2}{*}{ Показники } & \multicolumn{3}{|c|}{$\begin{array}{c}\text { II група ХСН зі знижФВ } \\
\text { із супутнім латентним ЗД }(\mathrm{n}=60)\end{array}$} & \multicolumn{3}{|c|}{$\begin{array}{l}\text { III група ХCH зі знижФВ } \\
\text { із супутнім ЗДА }(n=62)\end{array}$} \\
\hline & II ФK (n=16) & III ФK (n=44) & $\mathrm{p}_{1}$ & II $\Phi K(n=14)$ & III ФK (n=48) & $\mathrm{p}_{2}$ \\
\hline $\mathrm{Hb}(г / л)$ & $136,8 \pm 1,6$ & $135,5 \pm 1,4$ & $>0,05$ & $115,4 \pm 6,9 \#$ & $103,3 \pm 1,5^{*}$ & $<0,001$ \\
\hline $\mathrm{Rbc}\left(\times 10^{12} / л\right)$ & $4,7 \pm 0,07$ & $4,7 \pm 0,07$ & $>0,05$ & $4,4 \pm 0,27$ & $4,0 \pm 0,06^{*}$ & $<0,01$ \\
\hline КП & $0,88 \pm 0,016$ & $0,86 \pm 0,006$ & $>0,05$ & $0,78 \pm 0,05 \#$ & $0,76 \pm 0,01^{*}$ & $>0,05$ \\
\hline Hct (л/л) & $0,40 \pm 0,007$ & $0,40 \pm 0,004$ & $>0,05$ & $0,35 \pm 0,021 \#$ & $0,32 \pm 0,004^{\star}$ & $<0,01$ \\
\hline MCV (фрл) & $85,3 \pm 1,6$ & $85,3 \pm 1,0$ & $>0,05$ & $80,2 \pm 4,9 \#$ & $79,3 \pm 0,7^{\star}$ & $>0,05$ \\
\hline $\mathrm{MCH}(п г)$ & $29,2 \pm 0,5$ & $28,6 \pm 0,2$ & $>0,05$ & $26,1 \pm 1,6 \#$ & $25,3 \pm 0,3^{*}$ & $>0,05$ \\
\hline $\mathrm{MCHC}$ (г/л) & $342,9 \pm 4,6$ & $336,9 \pm 3,0$ & $>0,05$ & $325,8 \pm 19,9 \#$ & $319,8 \pm 3,3^{*}$ & $>0,05$ \\
\hline 3С (мкмоль/л) & $9,1 \pm 0,5$ & $8,4 \pm 0,2$ & $>0,05$ & $9,3 \pm 0,9$ & $8,1 \pm 0,4$ & $>0,05$ \\
\hline Феритин (мкг/л) & $118,0 \pm 16,6$ & $87,5 \pm 8,1$ & $>0,05$ & $66,4 \pm 7,4 \#$ & $52,5 \pm 3,7^{*}$ & $<0,05$ \\
\hline HT3 (\%) & $15,2 \pm 1,2$ & $13,0 \pm 0,5$ & $<0,05$ & $13,2 \pm 1,3$ & $10,7 \pm 0,6^{\star}$ & $<0,05$ \\
\hline 33ЗС (мкмоль/л) & $63,8 \pm 3,2$ & $65,1 \pm 1,1$ & $>0,05$ & $73,1 \pm 5,3$ & $77,5 \pm 1,5^{\star}$ & $<0,05$ \\
\hline
\end{tabular}

Примітки: $\mathrm{p}_{1}$ - достовірність відмінностей показників порівняно із групою пацієнтів II ФК ХСН і супутнім латентним ЗД; $p_{2}$ - достовірність відмінностей показників порівняно із групою пацієнтів ІІ ФК ХСН і супутньою ЗДА; \# - достовірність відмінностей між групами пацієнтів II ФК ХСН із супутньою ЗДА та латентним ЗД при р<0,05 (достовірність відмінностей середніх величин між групами розрахована за U-критерієм Манна-Уїтні); * - достовірність відмінностей між групами пацієнтів III ФК ХСН із супутньою ЗДА та латентним ЗД при р<0,05 (достовірність відмінностей середніх величин між групами розрахована за критерієм Стьюдента).

$(p<0,05)$ та достовірно вищий рівень 333С $(77,5 \pm 1,5)$ мкмоль/л $(p<0,05)$ порівняно із рівнями даних показників пацієнтів II ФК цієї ж групи феритин $(66,4 \pm 7,4)$ мкг/л, НТ3 $(13,2 \pm 1,3) \%, 333 \mathrm{C}$ $(73,1 \pm 5,3)$ мкмоль/л.

У групі хворих на ХСН зі знижФВ із латентним ЗД ІІІ ФК усі досліджувані показники червоної крові та обміну заліза були меншими порівняно 3 показниками пацієнтів II ФК цієї ж групи (р>0,05), однак достовірну відмінність було виявлено лише за значенням НТ3 $(13,0 \pm 0,5)$ проти $(15,2 \pm 1,2) \%$.

Таким чином, згідно з отриманими результатами проведеного дослідження серед гематологічних показників підтверджено клінічну значущість маніфестного ЗДу хворих на ХСН зі знижФВ ЛШ щодо вираженості порушення їхнього фрункціонального стану, найбільшою мірою, за рівнями $\mathrm{Hb}$, Hct та Rbc. У багатьох дослідженнях показано, що саме зниження рівня $\mathrm{Hb}$ при ХCH тісно корелює з ФК і ступенем тяжкості XCH, несприятливим її прогнозом, що проявляється збільшенням частоти госпіталізацій і летальності $[5,16]$. Доведено лінійний зв'язок між смертністю і рівнем $\mathrm{Hb}$ та $\mathrm{Hct}$ [10]. Так за 33 місяці спостереження за хворими на ХCH загальна смертність склала 22, 27 і $34 \%$ відповідно рівням Hct 40-44, 35-39 і <35 \% [3]. 
А в ретроспективному дослідженні ОРТІME продемонстровано збільшення ризику смерті та частоти повторних госпіталізацій на $12 \%$ при рівні гемоглобіну <120 г/л [13].

Отримані значення показників фрерокінетики свідчать про клінічну значущість наявності ЗДА у хворих на ХCH зі знижФВ щодо їх фрізичної активності за рівнями НТ3, феритину, 333С. Однак, що стосується латентного ЗД серед показників обміну заліза найпоказовішим щодо функціонального стану є НТ3, що узгоджується із результатами попередніх досліджень. Так згідно з літературними даними у хворих на ХCH за наявності ЗД як з анемією, так і без, НТ3 краще корелював із фрізичним станом і прогнозом, ніж вміст фреритину та С3 [11].

\section{Висновки}

У хворих на ХCH зі знижФВ ЛШ із супутнім ЗД спостерігали зменшення значень гематологічних показників та показників фрерокінетики зі збільшенням ФК СН. Ці зміни асоціюються з поетапним розвитком ЗД від латентного до маніфестного.

Найпоказовішими серед гематологічних показників та показників ферокінетики щодо фрізичної активності хворих на ХCH при ЗДА є Hb, Hct, Rbc, феритин та НТ3, низькі значення яких асоціюються 3 вищим ФК.

Зниження НТЗ свідчить про погіршення фрункціонального стану хворих на ХCH зі знижФВ із супутнім ЗД як з анемією, так і без.

Перспективи подальших досліджень спрямовані на вивчення особливостей клінічного перебігу хронічної серцевої недостатності у поєднанні із залізодефріцитом та визначення його впливу на якість життя пацієнтів.

\section{Список літератури}

1. Анемія-коморбідний стан : монографрія / [Г. В. Дзяк, Т. О. Перцева, В. А. Потабашній та ін.] ; за ред. академіка НАМН України, професора Г. В. Дзяка. - Донецьк, 2013. - 268 с. - (ISBN 978-966-331-472-3).

2. Воронков Л. Г. Пацієнт із XСН в Україні: аналіз даних популяції пацієнтів, обстежених у рамках першого національного зрізового дослідження UNIVERS / Л. Г. Воронков // Серцева недостатність. - 2012. - № 1 (1). - С. 8-13.

3. Дворецкий Л. И. Эндогенная инотропная стимуляция миокарда у пациентов с хронической сердечной недостаточностью и анемией / Л. И. Дворецкий, В. В. Желнов, Н. В. Дятлов // Российские медицинские вести. 2012. - № 17 (2). - С. 40-48.

4. Іванов В. П. Шляхи оптимізації діуретичної терапії торасемідом у пацієнтів із хронічною серцевою недостатністю / В. П. Іванов, Ю. В. Савіцька // Кардиология: от науки к практике. - 2017. - № 4 (28). - С. 7-19.

5. Ларина В. Н. Клинические проявления анемического синдрома и его значение в течении хронической сердечной недостаточности у больных пожилого возраста / В. Н. Ларина, Б. Я. Барт // Терапевтический архив. - 2014. № 3 (86). - C. 53-58.

6. Особливості перебігу хронічної серцевої недостатності з коморбідним залізодефріцитом, клініко-прогностичне значення корекції залізодефріциту / В. П. Іванов, М. О. Колесник, О. М. Колесник, Є. І. Іванова // Кардиология: от науки к практике. - 2015. - № 3 (16). - С. 61-85.

7. Серцева недостатність та коморбідний стан. Рекомендації Асоціації кардіологів України з діагностики та лікування хронічної серцевої недостатності (спеціальний випуск) / Л. Г. Воронков, К. М. Амосова, Г. В. Дзяк та співавт. // Український науково-практичний журнал для лікарів 3 проблем СН. - 2017. - № 1 (додаток 1). - 67 с.

8. Царалунга В. Н. Клинико-эпидемиологический анализ распространенности и причин развития анемии у больных с хронической сердечной недостаточностью / В. Н. Царалунга, Э. Л. Виноградова, Т. С. Заражевская // Лікарська справа. - 2008. - № 7/8. - С. 22-30.

9. Beneficial effects of long-term intravenous iron therapy with ferric carboxymaltose in patients with symptomatic heart failure and iron deficiency / P. Ponikowski, D. J. van Veldhuisen, J. Comin-Colet [et al.] // European Heart Journal. - 2015. Vol. 36. - P. 657-668.

10. Caramelo C. Anemia in heart failure: pathophysiology, pathogenesis, treatment, and incognitae / C. Caramelo, S. Just, P. Gil // Rev. Esp. Cardiol. - 2007. - Vol. 60. - P. 848-860.

11. Disordered iron homeostatis in chronic heart failure: prevalence, predictors, and relation to anemia, exercise capacity and survival / D. O.Okonko, A. K. Mandal, C. G. Missouris [et al.] // JACC. - 2011. - Vol. 58. - P. 1241-1251

12. Effects of intravenous iron therapy in iron-deficient patients with systolic heart failure: a meta-analysis of randomized controlled trials / E. A. Jankowska, M. Tkaczyszyn, T. Suchocki [et al.] // European Journal of Heart Failure. - 2016. Vol. 18. - P. 786-795.

13. Felker G. M. Anemia in patients with heart failure and preservd systolic function / G. M. Felker; W. G. Shaw, C. M. O'Connor // Am. Heart J. - 2006. - Vol. 151, No. 2. - P. 457-462.

14. Iron deficiency and heart failure: diagnostic dilemmas and therapeutic perspectives / E. A. Jankowska, S. von Haehling, S. D. Anker [et al.] // European Heart Journal. - 2013. - Vol. 34. - P. 816-829

15. Iron deficiency defined as depleted iron stores accompanied by unmet cellular iron requirements identifies patients at the highest risk of death after an episode of acute heart failure / E. A. Jankowska, M. Kasztura, M. Sokolski [et al.] // European Heart Journal. - 2014. - Vol. 35. - P. 2468-2476.

16. Iron status in patients with chronic heart failure / E. A. Jankowska, J. Malyszko, H. Ardehali [et al.] // Eur. Heart J. 2013. - Vol. 34, No. 11. - P. 827-834.

17. Rationale and design of Ferinject assessment in patients with iron deficiency and chronicheart failure (FAIR-HF) study: a randomized, placebo-controlled study of intravenous iron supplementation in patients with and without anaemia / S. D. Anker, J. C. Colet, G. Filippatos [et al.] // European Heart Journal. - 2009. - Vol. 11. - P. 1084-1091. 
References

1. Dziak, G.V., Pertsevam, T.O., Potabashnii, V.A. (2013). Anemiia - komorbidnyi stan [Anaemia - a comorbid state]. Donetsk: IMA-press [in Ukrainian].

2. Voronkov, L.H. (2012). Patsiient iz KhSN v Ukraini: analiz danykh populiatsii patsiientiv, obstezhenykh u ramkakh pershoho natsionalnoho zrizovoho doslidzhennia UNIVERS [A patient with CHF in Ukraine: an analysis of the data of the population of patients examined in the framework of the first national study UNIVERS]. Sertseva nedostatnist - Heart Failure, 1 (1), 8-13 [in Ukrainian].

3. Dvoretskiy, L.I., Zhelnov, V.V. \& Dyatlov, N.V. (2012). Endogennaya inotropnaya stimulyatsiya miokarda u patsiyentov s khronicheskoy serdechnoy nedostatochnostyu i anemiyey [Endogenous inotropic myocardial stimulation in patients with chronic heart failure and anemia]. Ross. meditsinskie vesti - Russian Medical News, 17 (2), $40-48$ [in Russian].

4. Ivanov, V.P. \& Savitska, Yu.V. (2017). Shliakhy optymizatsii diuretychnoi terapii torasemidom u patsiientiv iz khronichnoiu sertsevoiu nedostatnistiu [Ways of optimization of diuretic therapy of Torsaamid in patients with chronic heart failure]. Kardiologiya: ot nauki k praktike - Cardiology: From Science to Practice, 4 (28), 7-19 [in Ukrainian].

5. Larina, V.N., \& Bart, B.Ya. (2014). Klinicheskye proyavleniya anemicheskogo sindroma i ego znachenie $v$ techenii khronicheskoy serdechnoy nedostatochnosti u bolnykh pozhilogo vozrasta [Clinical manifestations of anemia syndrome and its significance in the course of chronic heart failure in elderly patients]. Terapevticheskiy arkhiv - Therapeutic Archive, 86 (3), 53-58 [in Russian].

6. Ivanov, V.P., Kolesnyk, M.O., Kolesnyk, O.M. \& Ivanova, Ye.I. (2015). Osoblyvosti perebihu khronichnoi sertsevoi nedostatnosti z komorbidnym zalizodefitsytom, kliniko-prohnostychne znachennia korektsii zalizodefitsytu [Course peculiarities of chronic heart failure with comorbid iron deficiency, clinical-prognostic significance of iron deficiency correction]. Kardiologiya: ot nauky k praktike - Cardiology: From Science to Practice, 3 (16), $61-85$ [in Ukrainian].

7. Voronkov, L.H., Amosova, K.M., \& Dziak, H.V. (2017). Sertseva nedostatnist ta komorbidni stany. Rekomendatsii Asotsiatsii kardiolohiv Ukrainy z diahnostyky ta likuvannia khronichnoi sertsevoi nedostatnosti (Spetsialnyi vypusk) [Heart failure and comorbid condition. Recommendations of the Association of Cardiologists of Ukraine for the Diagnosis and Treatment of Chronic Heart Failure (Special Issue)]. Ukrainskyi naukovo-praktychnyi zhurnal dlia likariv z problem SN Ukrainian Scientific-Practical Journal for Doctors on Problems of Heart Failure, 1 [in Ukrainian].

8. Caralunga, V.N., Vinogradova, Ye.L. \& Zarazhevskaya, T.S. (2008). Kliniko-epidemiologicheskiy analiz rasprostranennosti i prichin razvitiya anemii u bolnykh s khronicheskoy serdechnoy nedostatochnostyu [Clinical and epidemiological analysis of the prevalence and causes of anemia in patients with chronic heart failure]. Likarska sprava - Doctor's Business, 7/8, 22-30 [in Russian].

9. Ponikowski, P., van Veldhuisen, D.J., Comin-Colet, Ertl, G., Komajda, M., Mareev, V., McDonagh, T., et al. (2015). Beneficial effects of long-term intravenous iron therapy with ferric carboxymaltose in patients with symptomatic heart failure and iron deficiency. European Heart Journal, 36, 657-668.

10. Caramelo, C., Just, S. \& Gil, P. (2007). Anemia in heart failure: pathophysiology, pathogenesis, treatment, and incognitae. Rev. Esp. Cardiol, 60, 848-860.

11. Okonko, D.O., Mandal, A.K., Missouris, C.G., et al. (2011). Disordered iron homeostatis in chronic heart failure: prevalence, predictors, and relation to anemia, exercise capacity and survival. JACC, 58, 1241-1251

12. Jankowska, E.A., Tkaczyszyn, M., Suchocki, T. (2016). Effects of intravenous iron therapy in iron-deficient patients with systolic heart failure: a meta-analysis of randomized controlled trials. European Journal of Heart Failure, 18, 786-795. 13. Felker, G. M., Shaw, W. G., \& O'Connor, C. M. (2006). Anemia in patients with heart failure and preservd systolic function. Am. Heart J., 2 (151), 457-462.

14. Jankowska, E.A., von Haehling, S., Anker, S.D. (2013). Iron deficiency and heart failure: diagnostic dilemmas and therapeutic perspectives. European Heart Journal, 34, 816-829.

15. Jankowska, E.A., Kasztura M., Sokolski, M., Bronisz, M., Nawrocka, S., Oleskowska-Florek, W., et al. (2014). Iron deficiency defined as depleted iron stores accompanied by unmet cellular iron requirements identifies patients at the highest risk of death after an episode of acute heart failure. European Heart Journal, 35, 2468-2476.

16. Jankowska, E. A., Malyszko, J., Ardehali, H., Koc-Zorawska, E., Banasiak, W., von Haehling, S., et al. (2013). Iron status in patients with chronic heart failure. Eur. Heart J., 34(11), 827-834. doi: 10.1093/ eurheartj/ehs377.

17. Anker, S.D., Colet, J.C., Filippatos, G., Willenheimer, R., Dickstein, K., Drexler, H., et al. (2009). Rationale and design of Ferinject assessment in patients with iron deficiency and chronicheart failure (FAIR-HF) study: a randomized, placebocontrolled study of intravenous iron supplementation in patients with and without anaemia. European Heart Journal, 11, 1084-1091.

\section{ПОКАЗАТЕЛИ ОБМЕНА ЖЕЛЕЗА В ЗАВИСИМОСТИ ОТ ФУНКЦИОНАЛЬНОГО КЛАССА ХРОНИЧЕСКОЙ СЕРДЕЧНОЙ НЕДОСТАТОЧНОСТИ У ПАЦИЕНТОВ С СОПУТСТВУЮЩИМ ЖЕЛЕЗОДЕФИЦИТОМ}

М. О. Колесник

Винницкий национальный медицинский университет имени Н. И. Пирогова, г. Винница, Украина

Цель: проанализировать значения показателей красной крови и феррокинетики в зависимости от функционального класса (ФК) ХСН со сниженной фрракцией выброса (снижФВ) левого желудочка (ЛЖ) у пациентов с сопутствующим ЖД. 
Материалы и методы. В исследовании проведен анализ гематологических показателей и показателей феррокинетики 122 больных ХСН гипертензивной в сочетании с ишемической этиологией со снижФВ ЛЖ и сопутствующим ЖД в зависимости от величины ФК ХСН.

Результаты. Выявлено, что у больных сопутствующим латентным ЖД и железодефицитной анемией (ЖДА) с увеличением ФК ХСН уменьшаются показатели феррокинетики. В группе больных ХСН со снижФВ с сопутствующей ЖДА среди пациентов III ФК были достоверно ниже средние значения Hb, Hct, и количества Rbc по сравнению со средними значениями данных показателей пациентов II ФК этой же группы. Среди показателей фреррокинетики были достоверно ниже средние уровни ферритина, насыщения трансфреррина железом (НТЖ) и достоверно более высокий уровень общей железосвязывающей способности сыворотки (ОЖСС). В группе больных ХСН со снижФВ и латентным ЖД ІІІ ФК достоверное отличие была обнаружена только по значению НТЖ.

Выводы. Наиболее показательными среди гематологических показателей и показателей фреррокинетики по фризической активности больных XCH при ЖДА является Hb, Hct, Rbc, ферритин и НТЖ, низкие значения которых ассоциируются с высшим ФК.

Снижение НТЖ свидетельствует об ухудшении функционального состояния больных ХСН со снижФВ с сопутствующим ЖД как с анемией, так и без.

КЛЮЧЕВЫЕ СЛОВА: хроническая сердечная недостаточность; латентный железодефицит; железодефицитная анемия; показатели феррокинетики.

\section{INDICES OF IRON METABOLISM DEPENDING ON THE FUNCTIONAL CLASS OF CHRONIC HEART FAILURE AMONG PATIENTS WITH COMORBID IRON DEFICIENCY}

M. O. Kolesnyk

National Pirogov Memorial Medical University, Vinnytsya, Ukraine

Purpose: to analyze the significance of red blood cells and ferrokinetics, depending on the functional class (FC) of CHF with reduced left ventricular ejection fraction in patients with comorbid ID.

Materials and Methods. There was conducted the analysis of hematological parameters and parameters of ferrokinetics of 122 patients with CHF hypertensive in combination with ischemic etiology with a reduced fraction of left ventricular ejection and accompanying ID depending on the size of the functional class (FC) of CHF.

Results. It was revealed that among patients with concomitant latent ID and iron deficiency anemia, with increasing $\mathrm{FC}$ of $\mathrm{CHF}$, the parameters of ferrokinetics are decreasing. At the group of patients with $\mathrm{CHF}$ with a reduced fraction of left ventricular ejection and concomitant IDA among patients of III FC, the mean values of $\mathrm{Hb}$, $\mathrm{Hct}$ and Rbc were significantly lower than the average values of patients with II FC in the same group. Among the indicators of ferrokinetics were significantly lower average levels of ferritin, transferrin saturation with iron (TSI) and a significantly higher level of the total iron binding capacity of the blood serum (IBCS). In the group of patients with CHF with a reduced fraction of left ventricular ejection and latent ID among patients of III FC, a significant difference was found only in the value of TSI.

Conclusions. The most significant among the hematological and ferrokinetic indicators, for the physical activity of patients with CHF and IDA is $\mathrm{Hb}, \mathrm{Hct}, \mathrm{Rbc}$, ferritin and TSI, which low values associated with higher FC. A reduction in the TSI indicates a deterioration in the functional status of patients with CHF with a reduced fraction of left ventricular ejection and accompanying ID, both with and without anemia.

KEY WORDS: chronic heart failure; latent iron deficiency; iron deficiency anemia; indices of iron metabolism.

Рукопис надійшов до редакції 05.10.2018 p.

\section{Відомості про автора:}

Колесник Марія Олегівна - аспірант кафедри внутрішньої медицини № 3 Вінницького національного медичного університету імені М. І. Пирогова, тел.: +38(063) 653-39-12. 